\title{
st \\ Geração orgânica, acidente e herança na Carta XIV de Maupertuis
}

\author{
Maurício de Garvalho Ramos
}

\section{INTRODUÇÃO}

A Carta XIV. Sobre a geração dos animais faz parte de um conjunto de pequenos ensaios filosóficos e científicos acerca de temas diversos publicado pela primeira vez em 1752, em Dresde, com o título Cartas. Outras edições apareceram em ${ }_{175}^{3}$ (Berlim, Lyon), 1756 (Lyon) e 1768 (Lyon). A tradução do documento que aqui apresentamos foi feita a partir de uma reprodução em facsímile desta última edição. Segundo Beeson, a composição de tais cartas provavelmente ocorreu a partir de 1749 e fez parte do período mais promissor da carreira de Maupertuis, a saber, entre 1746 e 1751 (cf. Beeson, 1992, p. 228). Contudo, acreditamos que a importância específica da Carta XIV será melhor compreendida se a situarmos no conjunto de seus estudos em história natural e, assim, apresentaremos a seguir um resumo de seu desenvolvimento.

Pierre-Louis Moreau de Maupertuis (1698-1759) participou ativamente das academias científicas de seu tempo, sendo eleito em 1723 para a Academia de Ciências de Paris e em 1728 para a Royal Society

\section{E T T R E S D E}

M. DE MÁUPERTUIS.

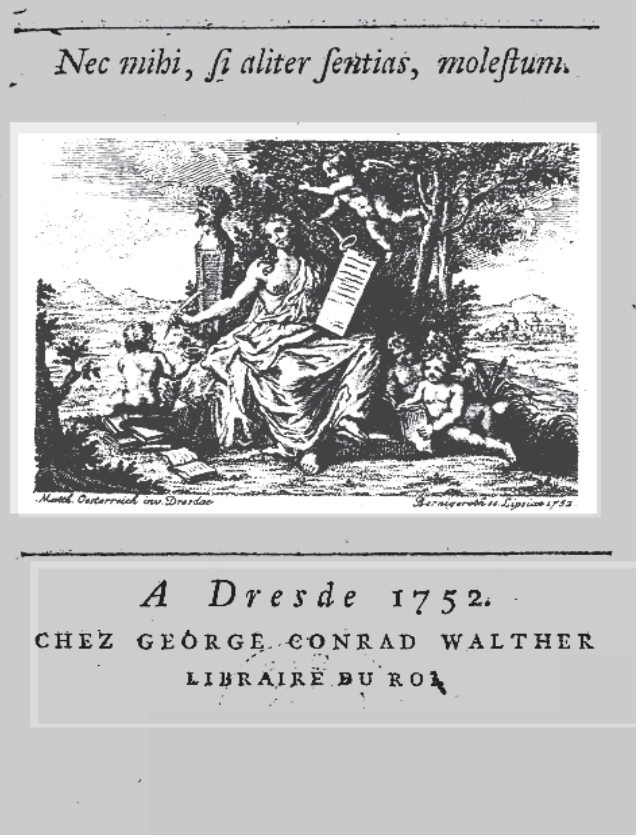

Figura 1. Página-título das Lettres de Maupertuis, editada em 1752. 
de Londres. Em 1744, foi convidado por Frederico is para a reorganizar a Academia de Ciências de Berlim, da qual foi presidente de 1746 até sua morte. Ardente defensor do newtonianismo na Academia Francesa, considerava-se o primeiro a propor, na França, a atração como princípio a ser examinado. São duas de suas realizações científicas bem conhecidas a demonstração empírica do achatamento da Terra nos pólos e a formulação do princípio de mínima ação. Nos dois casos, envolveu-se em intensas polêmicas com os discípulos de Descartes e Leibniz, respectivamente. Apesar de ser mais conhecido como físico, astrônomo e geômetra, Maupertuis também possui uma importante obra em história natural, iniciada bem antes de suas pesquisas físico-matemáticas e cujo tema central é o problema da geração dos organismos. No século xviII, tal problema integrava um vasto domínio de fenômenos que, apenas para efeito das análises que faremos neste ensaio, podemos dividir em três âmbitos distintos: o ontogenético, que inclui a reprodução, o ciclo de vida e o desenvolvimento dos organismos, o filogenético ou a história evolutiva das espécies e o genético, relacionado aos mecanismos de produção e transmissão das características e das mutações biológicas hereditárias.

O primeiro trabalho de Maupertuis nessa vertente foi um estudo sobre a anatomia e o modo de vida das salamandras, publicado em 1727 como Observações e experiências sobre uma das espécies de salamandra. $\mathrm{O}$ autor realiza uma série de experimentos no sentido de testar duas propriedades tradicionalmente a elas atribuídas: que são resistentes ao fogo e extremamente venenosas; ambas são refutadas. Interessado também em seu modo de reprodução, nelas observou a seguinte peculiaridade: "Tendo aberto algumas salamandras, surpreendi-me ao encontrar juntos dentro da mesma ovos e filhotes tão perfeitos quanto os dos vivíparos" (Maupertuis, 1727, p. 32). Embora não tenha sido empregado por Maupertuis, o termo ovovivíparo pode ser atribuído a estes animais, cujas fêmeas produzem ovos que eclodem ainda no interior do ventre materno. Tomando ainda a postura e a eclosão dos ovos como critérios, pode-se classificar os animais em mais duas categorias: os ovíparos, que colocam ovos no ambiente e, somente depois, deles saem os jovens e os vivíparos, como os mamíferos, que não põem ovos e o desenvolvimento do organismo ocorre no interior do útero.

Ao constatar a ovoviviparidade nas salamandras, Maupertuis faz sua primeira conjectura sobre a questão da geração: "Esse animais parecem bem próprios para esclarecer o mistério da geração, pois por mais variedade que haja na natureza, o âmago das coisas nela se passa da mesma maneira" (Maupertuis, 1727, p. 32). A existência dessa particularidade reprodutiva permitiu ao autor conjecturar que a viviparidade e a oviparidade não são modos irredutíveis de reprodução, mas apenas variações de um mesmo processo mais geral. Pode-se dizer que a busca de um tal princípio gerativo fundamental permaneceu desde então como meta constante nos estudos biológicos de Maupertuis e em 1752, ano em que publica a Carta XIV, ele escreverá: "para fazer da 
história natural uma verdadeira ciência é preciso que nos apliquemos em pesquisas que nos façam conhecer não a figura particular deste ou daquele animal, mas os processos gerais da natureza em sua produção e sua conservação" (Maupertuis, 1965, p. 417). Mas esta meta só será atingida após o enfrentamento de uma série de questões. Qual seria o papel dos ovos nesse processo ou princípio de produção e de conservação dos organismos? Serão eles, como reiteradamente afirmaram os ovistas contemporâneos do autor, as verdadeiras unidades reprodutivas de todos os seres vivos, ou seria o modo vivíparo de reprodução, como o dos mamíferos e dos humanos, o "modelo" mais geral? Talvez os ovos nada tivessem de essencial para a geração, havendo outras estruturas gerativas ainda mais elementares como os microscópicos vermes espermáticos descobertos por Leeuwenhoek: eles poderiam ser os estágios larvais de futuros animais adultos e, assim, a maneira pela qual certos insetos se reproduzem seria o modelo universal da geração. Por fim, a verdadeira substância prolífera poderia ser composta por estruturas ainda menores que os animálculos do sêmen e diferentes de qualquer organismo já visto: glóbulos animados, moléculas orgânicas ou partículas gerativas, encontradas tanto nos líquidos internos de machos e fêmeas como "nas infusões de plantas e nos sucos de carne cozidos" (Maupertuis, 1965, p. 3o3), seriam as partes mínimas da matéria dotadas de poderes gerativos. São problemas dessa natureza, acerca da ontogênese dos animais, que vemos Maupertuis enfrentar na Carta XIV.

Em 1729, ele realiza uma série de observações e experimentos com escorpiões, publicados no mesmo ano nas Experiências sobre os escorpiões. O trabalho versa basicamente sobre a potência do veneno e a morfologia dos animais (fig. 2), mas traz também rápidas observações sobre a quantidade de filhotes produzidos (Maupertuis, 1731, p. 228), sem qualquer referência teórica mais geral acerca da geração. Maupertuis realiza ainda alguns experimentos no sentido de mostrar a falsidade da crença de que estes animais se suicidam quando aprisionados em um círculo de fogo.

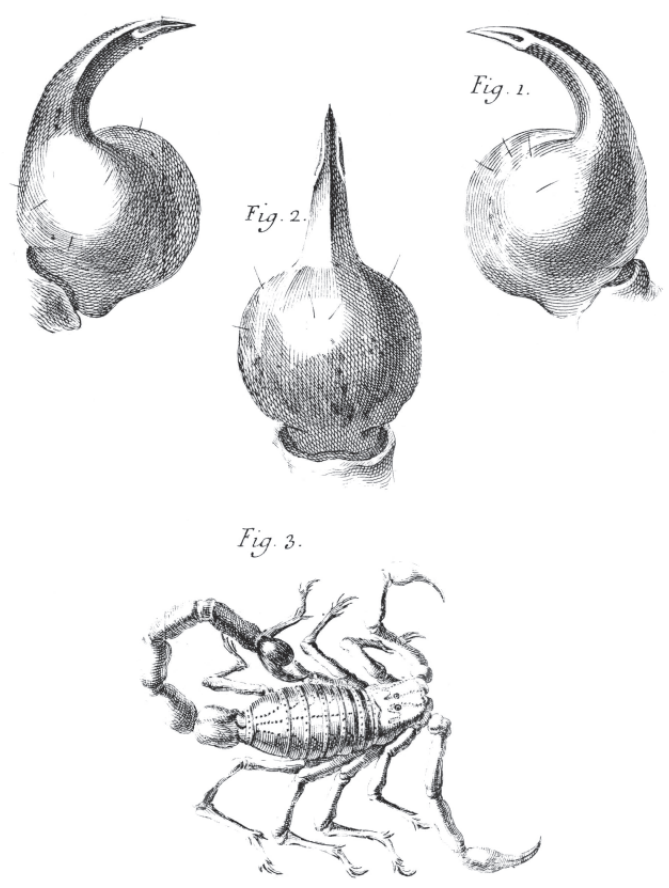

Figura 2. Ilustrações de aspectos da anatomia dos escorpiões estudados por Maupertuis em suas Experiências sobre os escorpiões, de 1729. Em 1 e 2, detalhe do aguilhão de veneno observado ao microscópio. 
Entre 1730 e 174,3, Maupertuis não publicou nenhum outro trabalho em história natural, mas podemos encontrar importantes questões sobre o tema em alguns de seus estudos astronômicos e físicos e no ensaio Reflexões filosóficas sobre a origem das línguas e o significado das palavras, de 1740. Identificar e organizar tais questões algo dispersas estaria fora do escopo desta breve introdução, bastando aqui mencionar que seus estudos sobre a forma dos planetas (sobretudo a da Terra), sobre o movimento dos astros (sobretudo o dos cometas) e sobre a origem da linguagem incluíram conjecturas sobre os efeitos que os possíveis eventos presentes na história da formação da Terra tiveram sobre a geração dos organismos e sobre a produção de novas raças e de novas espécies, especialmente as raças humanas. Cremos que foi nesse período que Maupertuis passou a incluir em sua história natural reflexões acerca dos aspectos filogenéticos da geração orgânica. Foi nele também, ou mesmo antes, que o autor conheceu a importante controvérsia existente na época acerca da origem dos monstros, travada entre os médicos Louis Lémery e Jacques-Bénigne Winslow. Este termo era atribuído aos organismos que nasciam com malformações de várias tipos, havendo os monstros por excesso, com um número de órgãos maior que o normal, os monstros por escassez, que exibiam mutilações diversas e os monstros produzidos por diversos graus de desorganização das partes corporais. Os dois adversários aceitavam a preexistência ovista, ou seja, que os embriões estavam completamente preformados no interior dos ovos antes mesmo da concepção (oportunamente trataremos mais detidamente dessa teoria), mas Lémery defendia que as malformações observadas eram causadas por acidentes ocorridos com o embrião no ventre materno, enquanto Winslow acreditava que os embriões eram originalmente defeituosos. Maupertuis leu nas páginas das Memórias e da História da Academia de Ciências de Paris os termos da célebre disputa e, assim, conheceu em detalhe as dificuldades envolvidas na explicação da causa e da herança das mutações, dificuldades que se relacionam com a dimensão genética do problema da geração. Segundo Hoffheimer (cf. 1982, p. 124), os estudos específicos em história natural de Maupertuis que apareceriam a partir de 1744 , constituem uma resposta direta aos problemas implicados na controvérsia dos monstros.

Em 1744 chega a Paris uma criança albina, um negre blanc, cuja exibição nos salões da cidade animou as discussões em torno da geração. Ao conhecer essa criança, Maupertuis defronta-se com um fenômeno cuja explicação exigiria uma resposta unificada para o conjunto de problemas que, desde seus primeiros trabalhos naturalistas, vinha amadurecendo paralelamente a suas pesquisas físico-matemáticas. Como seria possível que uma criança branca nascesse de pais negros? São tais nascimentos acidentes que desaparecem nas gerações futuras, ou esses indivíduos poderão constituir uma nova variedade ou raça humana? Seria essa criança um retorno, entre os negros, da raça branca ancestral? Temos aqui a combinação de questões genéticas e filogenéticas que 
será o principal objeto da Vênus física. Publicada em 1745, tornou-se a obra mais popular de Maupertuis e conheceu, no século xvııı, várias edições. No ano anterior, Maupertuis já publicara sua Dissertação física por ocasião do negro branco que, apesar do tema anunciado no título, não toca na questão da criança albina. Essa dissertação tornou-se a pri-

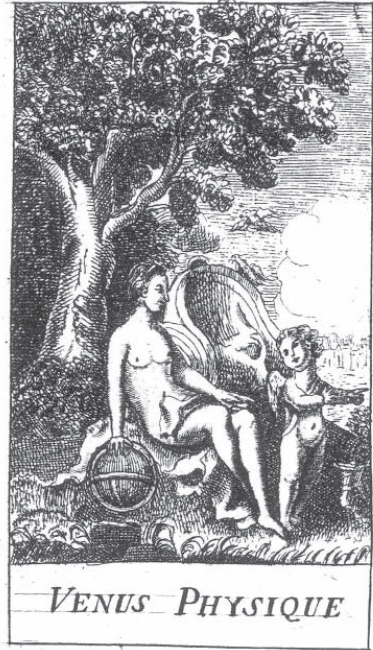
V E N U S PHYSIQUE. meira parte da Vênus física que recebeu, então, uma segunda parte dedicada às raças humanas, ao nascimento do negro albino e à produção de novas espécies.

A Vênus física contém a primeira

Figura 3. Página-título da sexta edição, de ${ }_{17} \mathbf{6}_{5}$, da Vênus física de Maupertuis.

teoria da geração de Maupertuis. Ela pode ser caracterizada, em linhas gerais, como uma versão moderna da teoria hipocrática da dupla semente (trataremos desta teoria no próximo item) reinterpretada à luz da química newtoniana. $\mathrm{O}$ embrião é formado a partir da mistura dos líquidos seminais produzidos pelos dois progenitores que contêm partículas gerativas oriundas de todas as partes corporais. A união de tais partículas ocorre graças à ação de forças especiais de atração na forma de afinidades químicas. Outros detalhes sobre a teoria serão apresentados mais adiante.

\section{DISSERTATION}

$P H Y S I Q U E$

\section{A L'OCCASION D U}

\section{NEGRE BLANC.}

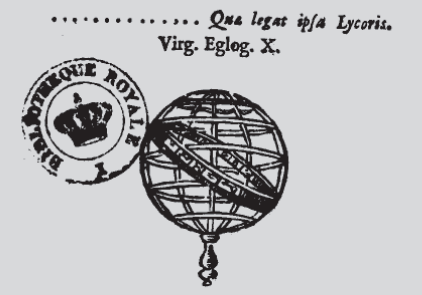
A L E Y D E,

M. DC.C. XLIV.

Finalmente, entre 1746 e $175^{1}$, os "anos de triunfo" de Maupertuis a que se refere Beeson, situase a época de composição das Cartas que contém o nosso documento. É também nesse período que Maupertuis publica o Ensaio de cosmologia, de $175^{\circ}$, e a Dissertação inaugural metafísica sobre o sistema universal da natureza, para obtenção do grau de doutor, de 1751. Na primeira obra há importantes referências à origem dos primeiros organismos e das primeiras espécies, discutidas em um contexto de controvérsia com a teologia natural newtoniana e com as concepções atomistas de Epicuro. Tratamos desse assunto em um outro artigo (cf. Ramos, 2003), onde também

Figura 4. Página-título da Dissertação física por ocasião do negro branco de Maupertuis, de $\mathbf{1 7 4 4}$. 
desenvolvemos outros aspectos da teoria de Maupertuis aqui mencionados mais superficialmente. A segunda obra, que em 1756 recebeu o título definitivo Sistema da natureza, contém a segunda e última versão da teoria da geração de Maupertuis. Nela o autor realiza uma grande modificação da teoria anterior substituindo as afinidades químicas por propriedades psíquicas, atribuídas diretamente às partículas gerativas. Graças ao desejo, à aversão e à memória presentes nessas partículas pode-se explicar, segundo Maupertuis, todos os fenômenos gerativos que desafiavam a ciência da época. Comparativamente à Vênus física, a nova teoria aplica-se a um campo mais vasto de fenômenos gerativos, cobrindo tanto os processos sexuados e assexuados (a regeneração dos pólipos e a partenogênese) como a geração espontânea. Acreditamos que é nessa obra que o autor encontra o princípio gerativo efetivamente universal que buscou ao longo de toda sua obra biológica.

É nesse ponto que podemos, então, situar o conteúdo da Carta xIV. Ela pode ser vista, primeiramente, como uma espécie de resumo dos principais problemas enfrentados por Maupertuis desde seus primeiros estudos, resumo que sintetiza os aspectos ontogenéticos, filogenéticos e genéticos da geração. Em segundo lugar, encontramos neste pequeno documento os originais estudos genéticos de Maupertuis, além de um importante conjunto de dúvidas ainda por resolver antes que se decidisse pela atribuição das propriedades psíquicas à matéria, sobretudo no que tange à natureza das verdadeiras e universais unidades gerativas. Tais estudos e problemas refletem de modo exemplar o estado das pesquisas presentes na metade do século xvirI entre autores que, como Buffon, Needham e Maupertuis, enfrentaram as teorias oficiais de sua época, sustentadas sob elegantes sistemas teológico-metafísicos, mas plenas de notórias inconsistências empíricas.

Tendo apresentado este resumo do desenvolvimento da história natural de Maupertuis, discutiremos nos próximos itens alguns aspectos particulares do conteúdo da Carta XIV. Para tanto, propomos uma divisão do documento em quatro partes principais que serão utilizadas como eixo de nossa discussão e que o leitor também poderá tomar como roteiro de leitura: (a) exposição das teorias antigas e modernas sobre a geração orgânica. A exposição dos antigos é fundamentalmente uma breve referência à teoria da dupla semente e, na segunda exposição, Maupertuis apresenta um resumo das teses básicas da teoria da preexistência dos germes nas suas versões ovista, animalculista e ovovermista; (b) crítica à teoria da preexistência a partir da teoria da geração de Buffon e de sua própria teoria, aquela apresentada na Vênus física. Nessa crítica, Maupertuis procura pôr em evidência o acordo existente entre as duas teorias. O problema central discutido é a existência dos ovos de vivíparos e a identidade biológica (morfológica e funcional) dos espermatozóides ou animálculos; como resultado dessa primeira crítica teórica, Maupertuis adota o sistema dos antigos; (c) reforço da crítica 
à preexistência através do exame de casos empíricos que provam a contribuição biparental na herança do número de dedos em animais e no homem; aqui Maupertuis apresenta inovadores estudos empíricos que realizou sobre a polidactilia; (d) retorno ao problema da identidade dos espermatozóides, agora inseridos no contexto do problema da geração espontânea a partir das observações e experimentos de Needham e Buffon sobre a questão; conclusão com a formulação de uma série de questões que revelam a perplexidade de Maupertuis diante do tema e que preparam as profundas modificações que aparecem implementadas no Sistema da natureza.

\section{A geraçÃo dos organismos ENTRE os ANTIgos}

$\mathrm{Na}$ Antigüidade, foram desenvolvidas várias teorias sobre a geração dos organismos como parte da filosofia natural de Empédocles, Anaxágoras, Demócrito, Hipócrates, Aristóteles, Epicuro, Lucrécio e Galeno, entre outros. Dentre as tantas idéias legadas por esses autores, Maupertuis refere-se praticamente apenas àquela que estará diretamente ligada a sua própria teoria, a saber, a idéia de que na geração dos animais há uma contribuição biparental em função da participação das sementes masculina e feminina de cuja mistura se forma o embrião. Podemos designar sinteticamente essa concepção como teoria da dupla semente e, apesar de Maupertuis afirmar no documento que os antigos adotaram a teoria "sem que soubessem e sem que se preocupassem muito em investigar como a coisa se produzia" (Maupertuis, 1965, p. 299), os vários autores mencionados procuraram explicar como tais matérias seminais eram produzidas, como ocorria a mistura de ambas no corpo da fêmea e, mais importante, como tais sementes interagiam mutuamente para formar o corpo do futuro organismo. Dentre as várias modalidades de explicação desses fenômenos, discutiremos brevemente aqui alguns aspectos das idéias de Hipócrates e Anaxágoras no sentido de colocar em evidência certas dificuldades que Maupertuis encontrará na construção de suas conjecturas a partir da teoria da dupla semente, então informada pela visão moderna do processo.

A idéia central da teoria da dupla semente aparece sinteticamente no texto hipocrático Sobre a geração: "A semente vem ao útero do corpo todo da mulher e do homem" (Hipócrates, apud Castañeda, 1992, p. 11). Nesta breve passagem, temos não apenas a indicação da existência de sementes nos dois sexos e a identificação do útero como local de sua reunião, como também a afirmação da origem de tais sementes: elas provêm de todas as partes corporais. Essa teoria para a origem da matéria seminal pode ser designada como pangênese e podemos ler alguns detalhes do processo em $A$ doença sagrada, outro texto do corpus hipocrático: 
Figura 5. Desenho de Leonardo da Vinci do coito de um homem e uma mulher hemidissecados, feito em 1492 ou 1493 . Comparando o desenho com a citação que fizemos de $A$ doença sagrada, podemos ver a existência de um canal que parte da espinha dorsal e penetra o pênis; por esse canal é conduzida "a parte mais forte e gordurosa" dos fluidos que constitui o sêmen, oriundo do cérebro e da medula. Percebe-se também que, conforme descreve o texto hipocrático, o pênis possui dois canais, um para conduzir a urina e outro o sêmen.

Quanto ao esperma do homem, ele vem de toda parte do humor que se encontra no corpo; é a sua parte mais forte que se separa [...]. Veias e nervos vão do corpo todo ao sexo [...]. Pelo atrito do sexo e o movimento que é feito, o humor aquece-se no corpo, torna-se fluido, agita-se por causa do movimento e espuma, como espumam todos os fluidos agitados. Da mesma forma, no homem separa-se do humor espumante a parte mais forte e mais gordurosa, que chega à medula espinhal. Pois ela aí chega do corpo inteiro e escoa do cérebro para as costas [...] Depois de ter chegado à medula, o esperma passa pelos rins [...] dos rins, o esperma passa através do meio dos testículos ao membro, não pelo canal da urina mas por um outro (Hipócrates, apud Castañeda, 1992, p. 8-9).

Explicações como essa tiveram vida longa na medicina e na história natural posteriores e iremos encontrá-la, por exemplo, ilustrada em um desenho de Leonardo da Vinci de 1492 ou 1493.

A explicação da formação do embrião é bem mais complexa e envolve muitos detalhes, mas podemos conhecer seu teor geral a partir da descrição de uma parte do processo gerativo encontrada em um terceiro texto hipocrático, Sobre a natureza da criança: 
A carne aumentada pelo sopro divide-se em membros; nela o semelhante vai ao seu semelhante, o denso ao denso, o frouxo ao frouxo, o úmido ao úmido; e cada coisa vai ao seu lugar próprio segundo a afinidade de onde ela provém; o que provém do denso é denso; do úmido, é úmido; e assim por diante no crescimento (Hipócrates apud Pichot, 1993, p. 21).

Calor e "sopros" produzidos por um processo fermentativo movimentam as partes da mistura seminal e mudanças locais, qualitativas e gerativas combinam-se para formar o embrião. Mas essas partes já contam com uma diferenciação prévia, representadas aqui por qualidades tais como densidade, textura, umidade etc. Tais qualidades foram adquiridas no processo pangenético de formação da semente-cada parte seminal possui a qualidade do órgão parental de onde proveio. A associação de partes seminais semelhantes restitui o mesmo tipo de organização que possui o corpo dos pais e, assim, os dois sexos participam igualmente da geração. Um último ponto completa este nosso quadro da teoria hipocrática. Ainda sobre a origem pangenética das sementes e a herança biparental de caracteres, lemos em $A$ doença sagrada o seguinte: "Como a semente vem de todas as partes do corpo, partículas saudáveis virão de partes saudáveis, e partículas não saudáveis de partes não saudáveis" (Hipócrates, 1952, p. 155). Vemos claramente que tanto os traços normais como os alterados são igualmente herdáveis e, além disso, há aqui uma referência à natureza corpuscular da semente que, como veremos, será essencial para a teoria de Maupertuis.

Dos elementos até aqui expostos, podemos colocar em destaque aqueles que, na seqüência desta discussão introdutória, serão mais relevantes para o contexto em que a geração é tratada na Carta XIV. Em Hipócrates, a semente é dupla e possui uma origem pangenética; mas disto decorre também que ela é claramente heterogênea, ou seja, composta por partes que apresentam diferentes atributos. Assim, temos uma diferenciação prévia ou uma preformação da semente anterior à concepção ou mistura dos licores seminais. Esse ponto é fundamental na medida em que se identifica, em parte, com as teorias modernas que Maupertuis rejeitará em prol justamente da adoção do "sistema dos antigos". Isso ficará mais claro a seguir, quando tratarmos das idéias de Anaxágoras.

As homeomerias de Anaxágoras vinculam a constituição e a geração dos corpos. Sobre elas diz Lucrécio:

[o que Anaxágoras] chama homeomeria das coisas é que, por exemplo, os ossos sejam constituídos por pequeníssimos, diminutos ossos, que as vísceras se formam de vísceras diminutas, pequeníssimas, que o sangue surja do juntar entre si de muitas gotas, que o ouro, segundo o que [ele] pensa, possa ser constituído 
por partículas de ouro, que a terra nasça de terras, o fogo de pequenos fogos, e a umidade de umidades; e acha que tudo se forma do mesmo modo (Lucrécio, 1973, p. 49).

O ponto mais importante para o problema da geração presente em tal concepção de homeomeria pode ser assim resumido: as partes de um todo possuem a mesma forma do todo e, assim, também estão preformadas. Segundo Simplício, para Anaxágoras todas as coisas estão subjacentes antes mesmo de serem geradas porque "no todo havia ouro, gerava-se ouro, e porque havia terra, gerava-se terra, e assim também cada uma das outras coisas, que não se engendravam, mas já antes eram subjacentes" (Simplício, 1973, p. 264). A mesma idéia é narrada por Aristóteles: “Anaxágoras [...] dizia que todas as coisas estão misturadas em todas e a geração é engendrada pela separação [...] supunha a partir desses fatos que também todos os seres estavam outrora misturados em conjunto, antes de terem sido separados" (Aristóteles, 1973, p. 265).

Temos aqui uma espécie de condição primordial do mundo, um estágio inicial onde as sementes de todas as coisas estão juntas e formam os corpos por separação. Parece-nos plausível que as gerações regulares dos organismos vivos ocorram por um processo análogo. Segundo São Gregório, Anaxágoras disse que "no próprio sêmen estavam contidos tanto o cabelo como as unhas e artérias e nervos e ossos, e que estes ali estavam invisíveis, por causa de sua pequenez, mas que se desenvolviam pouco a pouco, ao se separarem. Pois como poderia o cabelo provir do não-cabelo e a carne da não-carne?" (Gregório, apud Papavero \& Balsa, 1986, p. 81). Não temos aqui propriamente uma descrição do processo de geração dos organismos, mas é plausível que o sêmen a que se refere São Gregório é aquele encontrado no interior de animais já formados. O nous ou o espírito, que aparece em Anaxágoras como segundo princípio ao lado das homeomerias, é responsável pela separação das partes. A esse respeito diz Platão "Certo dia ouvi alguém ler de Anaxágoras, como dizia, que uma mente [nous] é a coordenação e a causa de tudo" (1973, p. 265) e Simplício afirma que, segundo Teofrasto, "Anaxágoras faz infinitos os princípios materiais e única a causa do movimento e da geração, a saber, o espírito" (Simplício, 1973, p. 263).

Em resumo, se considerarmos essas idéias sobre o mecanismo de geração atribuídas a Anaxágoras como aplicáveis aos corpos vivos, poderemos dizer que os semens paterno e materno devem conter partes seminais preformadas para todos os caracteres do futuro organismo, além de um número infinito de partes responsáveis pelos atributos ou caracteres de todos os demais corpos existentes. Os organismos são formados pela ação do espírito que separa e coordena as partes que lhes são próprias, tornandoas mais "evidentes". A natureza heterogênea da semente é, portanto, semelhante àquela descrita em Hipócrates, diferindo contudo quanto ao agente e ao processo organiza- 
dores das partes seminais. Essas idéias de Anaxágoras também influenciarão muitas das investigações posteriores sobre a geração, chegando até Maupertuis e alguns de seus contemporâneos:

Maupertuis não esconde a herança sobre a qual se edifica sua conjectura: transmitida por Lucrécio, a fortuna da "homeomeria de Anaxágoras" (De Natura, I, v. $835^{-84}$ o) foi assegurada pela analogia que persistirá ao longo de todas as teorias da geração após a Antigüidade: a analogia entre a agregação de cristais de sal e a unificação de partículas viventes, cujo menor mérito é o de substituir o esquema dos germes acumulados pelo dos germes preexistentes (Ibrahim, 1992, p. 96).

\section{As teORIAS MODERNAS: DA PREFORMAÇÃo À PREEXISTÊNGIA DO GERME}

O que dissemos até aqui acerca dessas duas concepções antigas sobre a geração receberá forte oposição de Aristóteles, cujas idéias sobre o tema serão, juntamente com as de Galeno, aquelas que a tradição posterior aceitará. Na verdade, há uma complexa interação de elementos antigos e medievais que não podemos apresentar mesmo resumidamente. Assim, na seqüência do texto, exploraremos as idéias anteriormente apresentadas visando diretamente os problemas contidos na Carta XIV.

A noção de que os organismos estão preformados no corpo dos parentes é uma idéia cuja importância está intimamente ligada ao desenvolvimento das teorias sobre a geração a partir do século xviı. Como vimos, essa noção já aparece em algumas teorias antigas, claramente como preformação de partes (Hipócrates) e, possivelmente, também como preformação de "todos" orgânicos (Anaxágoras). A utilização dessa noção implica um problema fundamental: se o osso é formado de pequenos ossos, o ouro de "pequenos ouros" e, da mesma maneira, são formados todos os corpos, então, do que é formado um homem - ou qualquer outro animal - enquanto organismos completos? Seria de "pequenos homens" ou de ossos que são formados de pequenos ossos, carnes que são formadas de pequenas carnes, e assim sucessivamente para todos os órgãos? Por fim, seriam partículas cuja forma em nada se assemelha às partes orgânicas que formarão o embrião, mas cuja reunião gradativamente vai restituindo a forma do organismo?

Temos aqui um problema clássico de níveis de organização biológica que permanecerá na história das ciências da vida e chegará até os debates contemporâneos entre concepções organicistas e reducionistas: definir qual é a unidade de organização e de funcionamento dos seres vivos, se tais unidades devem necessariamente ser também "orgânicas" ou se elas são unidades comuns aos corpos brutos e, por fim, identificar que leis, princípios e forças são suficientes para produzir e manter os seres organizados. 
A discussão que encontramos na Carta XIV acerca da identidade dos espermatozóides e dos ovos, na qual Maupertuis compara suas idéias às observações de Buffon e de Needham, pode ser lida como a expressão moderna desse problema. E é essencialmente esse mesmo problema a que Maupertuis se refere quando introduz, a partir do segundo parágrafo do documento, a solução dos "físicos modernos": todos os organismos vivos existem desde a criação do mundo como miniaturas preformadas no interior dos pais. Trata-se da teoria da preexistência dos germes, principal alvo da crítica de Maupertuis e que passaremos a discutir.

Diferentemente das teorias antigas examinadas, a teoria da preexistência exige que o embrião não apenas esteja sempre totalmente formado antes da concepção, mas também que ele exista antes mesmo dos próprios pais e de todos os seus ascendentesexcetuando-se o primeiro casal de cada espécie, criados por Deus já com seus germes. Essa teoria aparece em duas versões: a primeira, designada pelo termo panspermia, entende que os germes criados por Deus estão espalhados pelo ambiente e que, no momento adequado, penetram nas fêmeas - ela guarda, pois, algumas semelhanças com as homeomerias. A segunda, associada à noção de embutimento, afirma que os embriões estão desde a criação no interior do corpo dos parentes, encaixados ou embutidos, de geração em geração, uns dentro dos outros. Foi esta segunda versão que se estabeleceu no século xvIII e a vemos exposta e criticada na Carta XIV.

A história do estabelecimento da noção de preexistência é complexa, pois se sobrepõe ao desenvolvimento da noção de preformação em vários pontos. A distinção das duas noções não era explícita entre os autores que as criaram, tendo sido proposta apenas mais recentemente nos estudos de Jacques Roger, onde encontramos uma cuidadosa reconstrução histórica de como a noção moderna de preexistência emerge da idéia hipocrática de preformação. Segundo o autor, participaram dessa mudança teórica um conjunto de autores que vão de Parisanus (1567-1643) a Gassendi (1592-1655), sendo dois nomes de destaque Liceti e Aromatari (cf. Roger, 1993, p. 121-140).

Os primeiros elementos da noção propriamente de preexistência, ainda segundo Roger, aparecem por volta de 1660. Claude Perrault (1608-1680), médico e arquiteto francês, declara ter sido o primeiro a propor a doutrina, mas é na História geral dos insetos de Swammerdan (1637-1680) que ela é fortemente expressa pela primeira vez (cf. Roger, 1993, p. 334). Nessa obra, publicada em 1669, o autor apresenta estudos detalhados sobre a anatomia dos insetos. Dissecando a larva de uma borboleta, observou no seu interior um inseto adulto completamente formado. Com tal resultado, negou que os insetos sofriam verdadeiras metamorfoses quando passavam de uma fase para outra (ovo, larva, ninfa e adulto, no caso da borboleta). Em todas elas estava presente um mesmo animal - o adulto - que, na medida em que crescia, perdia seus envoltórios ou peles. A tal perda de envoltórios são associados os termos desenvolvimento e evolução. 
Swammerdan afirma ainda que "poderíamos mesmo deduzir [...] desse princípio a origem de nossa corrupção natural, concebendo que todas as criaturas estiveram encerradas nos rins de seus primeiros pais" e, comentando essa passagem, Roger diz que "de uma só vez, Swammerdan afirma a preexistência e o embutimento dos germes, embora não possuísse o nome e não dê à idéia toda sua clareza" (1993, p. 334). A noção aparece posteriormente de forma mais clara em seu Milagre da natureza, de 1672, onde afirma que o germe preexistente encontra-se dentro do ovo, que todos os ovos humanos encontravam-se em Eva e que, acabados esses ovos, será o fim do gênero humano (cf. Roger, 1993, p. 335). Posteriormente, essa idéia espalha-se e muito dos autores que anteriormente afirmaram apenas a preformação do germe foram apontados como precursores ou defensores da preexistência.

Malebranche também aparece como figura central na formulação da teoria da preexistência dos germes no século xviı. Ele dota a noção com um estatuto filosófico mais forte, ligando-a a diversos aspectos da filosofia da época, em especial ao mecanicismo. Observando o interior do bulbo de uma tulipa, encontra uma planta completamente formada, inclusive com flores. Generalizando a ocorrência do fenômeno para todos os vegetais, Malebranche afirma que toda a árvore encontra-se em miniatura no interior de sua semente e que cada miniatura possui igualmente suas sementes contendo árvores ainda menores e assim por diante até o infinito. Se nossa imaginação não pode conceber um tal estado de coisas é devido à sua limitação, pois a idéia de preexistência por embutimento "parece impertinente e bizarra apenas àqueles que medem as maravilhas da potência infinita de Deus com as idéias de seus sentidos e de sua imaginação" e, acrescenta, "temos demonstrações evidentes e matemáticas da divisibilidade da matéria ao infinito; e isso basta para nos fazer crer que possa haver animais menores e menores ao infinito, mesmo que nossa imaginação se choque com tal pensamento" (Malebranche apud Roger, 1993, p. 336). Veremos que esta mesma relação entre a divisibilidade infinita da matéria e dos organismos estará presente na Carta XIV.

Das plantas, Malebranche passa aos animais. Tomando as observações de Malpighi e Swammerdan, conclui que:

todos os corpos dos homens e dos animais que nascerão até a consumação dos séculos foram talvez produzidos desde a criação do mundo; eu quero dizer que as fêmeas dos primeiros animais foram talvez todas criadas com todos aqueles da mesma espécie que eles engendraram e que deverão engendrar na seqüência dos tempos (Malebranche, apud Roger, 1993, p. 337).

Essas idéias de Malebranche aparecem acopladas ao conjunto de sua filosofia e, em especial, à sua crítica a Descartes. A teoria da preexistência pode ser entendida 
como uma resposta ao mecanicismo cartesiano, aplicado à questão da geração dos organismos. Descartes afirmou que poderia explicar apenas com as leis do movimento como o embrião se forma a partir da mistura dos líquidos seminais. Além de seus resultados não serem por si só convincentes, eles apontavam para a possibilidade de que a natureza poderia agir autonomamente na produção ou criação de seres vivos e do homem. Tal idéia foi considerada um passo para a eliminação da ação de Deus na produção de fenômenos particularmente significativos. Com a preexistência, a produção dos seres vivos passa a ser uma prerrogativa exclusiva de um ser Criador, ficando a natureza e suas leis incumbidas apenas do crescimento dos embriões de origem divina. No final do século xviı, a teoria da preexistência dos germes invadiu o pensamento biológico e nele permaneceu até o século xıx, quando, então, morre lentamente.

A preexistência por embutimento apareceu em duas conhecidas versões, o ovismo e o animalculismo: a primeira postula que a seqüência de germes preformados e embutidos estão contidos nos ovos e a segunda, nos recém descobertos espermatozóides. Na verdade, há também uma espécie de versão híbrida, um “ovovermismo”, mas que pode ser incluído como uma modalidade de preformação animalculista já que também atribui papel gerativo aos espermatozóides.

A idéia de preexistência associada à teoria ovista exige a existência universal dos ovos, incluindo os ainda invisíveis ovos dos mamíferos e, principalmente, das mulheres. Essa tese fundamental do ovismo, cujo estabelecimento ou aceitação ocorreu mais ou menos independentemente das noções de preformação e preexistência, teve Harvey como autor central. Como aristotélico, ele concebia a geração orgânica de modo inteiramente oposto à vertente hipocrático-atomista e suas idéias podem ser consideradas, em relação à preexistência ovista, uma espécie de “ovismo antes dos ovos".

A "descoberta” dos ovos dos mamíferos é atribuída a Graff e aparece em seu Dos órgãos das mulheres, publicado em 1672. Graff observou os ovários e o útero de coelhas dissecadas em vários intervalos de tempo após a cópula. Verificou que os ovários mudam durante a vida das fêmeas e que tais mudanças estão associadas aos períodos de fertilidade. No século xvı, Vesálio já havia observado modificações nos ovários que designou por vesículas hidáticas, mas interpretou-as como causadas por infecções. Graff verifica que tais vesículas estão sempre presentes em animais férteis e que, após a cópula, algumas parecem perder seu conteúdo e deixam uma cicatriz em seu lugar. Observa também que o número de cicatrizes no ovário geralmente corresponde ao número de embriões encontrados no útero de fêmeas grávidas (cf. Gasking, 1967, p. 38). Com tais resultados, Graff expõe claramente em sua obra a tese ovista: "Podemos dizer sem temor de engano que as fêmeas de todos os tipos de animais têm ovos, dado que nelas eles se encontram não apenas nas aves e nos peixes como nos ovíparos e vivíparos, mas ainda nos quadrúpedes e mesmo na mulher" (Graaf, 1991, p. 3o). Estabelecida ou 
fortemente sugerida, a universalidade dos ovos une-se à idéia de preexistência para formar o que viria a ser a teoria embriológica oficial na época de Maupertuis.

Quanto à versão animalculista da teoria, praticamente tudo o que é afirmado para os ovos na versão ovista é aplicado aos espermatozóides ou “animálculos" espermáticos: os embriões em miniatura embutidos uns nos outros se encontram no interior destas estruturas e, desde a criação, vão sendo desembutidos de pai em pai para formar as várias gerações de todas as espécies. Analogamente ao que acontecia ao ovo em relação ao ovismo, o problema agora está em demonstrar a universalidade e definir a natureza e a função desses animálculos na geração dos organismos.

A descoberta dos espermatozóides é disputada por dois holandeses, Leeuwenhoeck e Hartsoecker. Roger (cf. 1993, p. 302) discute os termos dessa disputa e atribui a descoberta ao primeiro autor, que anuncia suas primeiras observações em uma carta à Royal Society de Londres em novembro de 1677 .

Além dos espermatozóides, Leeuwenhoeck observou pequenos "vasos" entre as partes diminutas do sêmen. São a essas estruturas que o autor atribui inicialmente papel importante na geração sem ainda associá-las aos espermatozóides. Tal associação aparece apenas em 1679, quando escreve:

os testículos foram feitos apenas no sentido de fornecer os pequenos animais e de conservá-los até sua emissão [...] aqueles que sempre tentaram sustentar que os animálculos eram produzidos da putrefação e não serviam para a geração estarão vencidos [...]. Eu penso que esses animálculos são compostos de um número de partes tão grande quanto o é nosso corpo segundo a opinião comum" (Leeuwenhoeck, apud Roger, 1993, p. 3०6).

Nessa passagem, vemos que a idéia de uma preformação do embrião no interior dos animálculos começa a aparecer, mas Leeuwenhoeck ainda não aceita que eles sejam também preexistentes. A possibilidade que resta é que os espermatozóides - com seus embriões - devem nascer no interior dos organismos. Mas nascer a partir do quê? Sobre isso diz Leeuwenhoeck:

de onde diríamos que sai o grão de onde nascem os animais, grão que está presente nos testículos das bestas, das aves - e aparentemente dos seres humanos e na leitosidade dos peixes? E isso, em verdade, é o único ponto que eu não posso resolver de maneira satisfatória. Pois se supusermos que eles estavam em nosso corpo desde nosso nascimento, ou mesmo desde o momento em que fomos engendrados, estes grãos, na minha opinião, não poderiam permanecer em nosso corpo durante dezesseis anos ou mais sem produzir vida, pois eu estou persuadido 
que quando há nos testículos animálculos que receberam a vida, eles devem desejar a união sexual. Mas estas coisas são apenas suposições e eu estou decidido a continuar minhas pesquisas sobre o tema no melhor de minhas possibilidades (Leeuwenhoeck, apud Roger, 1993, p. 3०6-7).

Os espermatozóides nascem de um grão ou semente contidos nos testículos, mas a origem desses grãos e quando eles começam a produzir - dotar de vida - os espermatozóides ainda são problemas não resolvidos por Leeuwenhoeck. O mesmo se dá para o embrião preformado no interior do animálculo que existe, mas não se pode explicar a origem.

Leeuwenhoeck retoma suas pesquisas sobre a questão em 1680. Examinando os testículos de um rato descobre junto dos animálculos normais outros menores e ainda não desenvolvidos. Não sendo preexistentes, eles nascem, provavelmente de um ovo, e crescem. Mas a origem desse ovo e do embrião que está no animálculo ainda permanecem obscuras. O autor apresentará um sistema de idéias mais completo em 1683, o qual oporá ao ovismo, já bem desenvolvido na época. Esse sistema marca, afirma Roger, o nascimento da doutrina do animalculismo: os seres humanos não vêm de um ovo, mas de animálculos, que podem ser machos ou fêmeas. Apenas um deles fixa-se no útero, onde se transforma em um organismo completo, ou seja perde sua pele e "o interior do corpo do animálculo toma a figura de um ser humano, já preparado com um coração e as outras partes internas e tendo verdadeiramente toda a perfeição de um homem" (Leeuwenhoeck, apud Roger, 1993, p. 309). Apesar de tais afirmações, Leeuwenhoeck jamais comunicou ter observado qualquer detalhe da estrutura interna dos espermatozóides. Suas afirmações nesse sentido são de caráter puramente teórico e, segundo Roger, feitas mais para responder às críticas do que como uma conseqüência do desenvolvimento de suas pesquisas. Essa doutrina animalculista não aparece, em Leeuwenhoeck, associada à preexistência e ao embutimento dos embriões e serão outros autores que farão tal associação. Entre eles, aparece Hartsoecker, o segundo autor envolvido na descoberta dos espermatozóides.

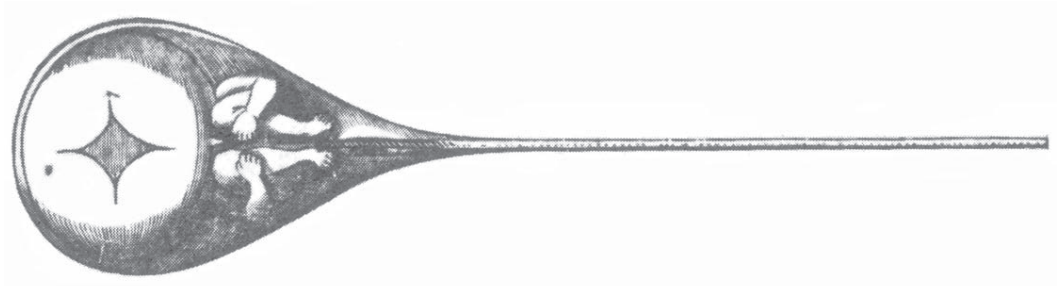

Figura 6. Ilustração de um homúnculo preformado na cabeça de um espermatozóide do Ensaio de dióptrica (1694) de Hartsoecker. 
Hartsoecker admitia explicitamente a preexistência e o embutimento dos animálculos. O autor apresentou em seu Ensaio de dióptrica, de 1694, as observações que se tornaram famosas sobre a existência de um homúnculo no interior dos espermatozóides. Sua figura de um pequeno homem abraçando as pernas e com uma grande cabeça ficou famosa nos meios acadêmicos e em toda referência posterior à questão (fig. 6). Mas Hartsoecker disse que tal homúnculo seria o que poderia ser visto caso a pele do animálculo fosse removida. Não diz ter removido essa pele e observado diretamente o que desenhou. O autor foi criticado por Leeuwenhoeck e, posteriormente, rejeitou a própria preformação (cf. Roger, 1993, p 318).

Em 1686-7, é editado o primeiro conjunto de cartas de Leeuwenhoeck e a teoria animalculista já aparece exposta com precisão. Recebe adeptos, mas também muitos críticos. Mesmo já sendo no início do século xviıI uma importante adversária do ovismo, apresenta problemas difíceis de serem superados. Sua aceitação foi lenta e na segunda metade desse século conta com poucos adeptos.

\section{A Grítica de Maupertuis À PREeXistÊncia}

Parte importante da Carta XIV é dedicada ao ataque às teorias modernas que acabamos de expor. A primeira crítica dirige-se ao papel dos milagres nas explicações científicas: se vamos recorrer a um milagre para explicar a geração dos embriões, que diferença faz entre dizer que todos eles foram produzidos ao mesmo tempo ou sucessivamente, sendo que cada nascimento constitui um novo milagre? Esses aspectos metafísicos da questão são mais desenvolvidos por Maupertuis em outras de suas obras e na Carta XIV o que está em jogo é, conforme mencionamos no início, principalmente o problema dos níveis de organização biológica. A preexistência, além de não avançar qualquer explicação natural para a própria geração, inclui ainda uma nova dificuldade: conceber a seqüência infinita de embriões cada vez menores e encaixados uns nos outros. Ao ler o documento, veremos que boa parte de sua discussão é feita no sentido de estabelecer o quão “orgânica” deve ser a parte mínima corporal capaz de reter o poder de gerar um novo organismo; em outras palavras, trata-se de definir a natureza da unidade reprodutiva dos seres vivos, problema cuja solução aceita pela biologia atual começará a ser formulada somente após a proposição da teoria celular, no final do século xIx.

Nesse sentido, os embriões preformados da teoria da preexistência exigem um grau máximo de organização da unidade reprodutora, já que a semente é apenas o pró-

prio adulto em miniatura. O que se vê da morfologia dos ovos e dos espermatozóides são meros envoltórios que serão perdidos com o crescimento do germe. Com isso em vista, podemos compreender porque Maupertuis, crítico da preexistência, evoca no 
documento os resultados que Buffon apresenta em sua recém publicada História natural. Negando a existência de ovos de mamíferos, Buffon destrói a universalidade dos ovos exigida pela preexistência ovista; mais ainda, esses corpos glandulares dos mamíferos não são ovos, mas estruturas que o autor viu “crescer, abrir-se e deixar escorrer um líquido no qual percebeu-se os mesmos animálculos ou os mesmos glóbulos animados que se tinha por animais na semente do macho" (Maupertuis, 1965, p. 3o2). Buffon, através de "observações incontestáveis", encontrou espermatozóides nas fêmeas e, assim, nem os ovos nem os animálculos do esperma seriam as verdadeiras unidades reprodutoras. O autor examinou o esperma masculino humano e de vários animais nos quais os animálculos espermáticos foram observados sob a forma de glóbulos que se desprendiam progressivamente de filamentos e os mesmos glóbulos móveis foram encontrados no líquido interno dos corpos glandulares do ovário de mamíferos (folículos de Graff), com e sem cauda (fig. ₹). Finalmente, o que para Maupertuis é "ainda mais maravilhoso", eles foram vistos nas várias infusões preparadas com a carne de diferentes animais e com sementes de vinte espécies de plantas diferentes (Buffon, 1853, p. 84). A partir dessas observações Buffon conclui que as unidades estruturais e reprodutivas atuantes em todas as formas de geração conhecidas são partes orgânicas ou, como dirá posteriormente, moléculas orgânicas:

Figura ₹. Lâmina da História natural de Buffon contendo os desenhos feitos durante as experiências realizadas com Needham em 1748 .

Desenhos 1 a 8: sêmen humano obtido "das vesículas seminais de um homem, morto violentamente, cujo cadáver estava todavia quente".

Desenhos 9 a 12: sêmen humano obtido de um segundo cadáver "também recente e que ainda não havia esfriado".

Desenhos 13 a 15: sêmen de um cão "expelido, em bastante quantidade, por uma emissão natural". Desenho 16: líquido obtido por infusão dos testículos de um cão.

Desenho 17 e 18 : sêmen de coelho obtido em animais dissecados.

Desenho 19: sêmen de cão emitido naturalmente.

Desenho 20: líquido obtido do "testículo" de uma cadela que "quatro ou cinco dias antes havia entrado em calor e à qual não se havia aproximado nenhum macho" e no qual Buffon diz que teve "a satisfação de reconhecer corpos semoventes com caudas, os quais eram quase absolutamente semelhantes aos que acabara de ver no licor seminal do cão".

Desenhos 21 e 22: mesmo tipo de líquido coletado em uma outra cadela.

Desenho 23: líquido obtido dos "corpos glandulares" de um "testículo" de vaca recém sacrificada.

Desenho 24: líquido obtido por infusão de um "testículo" de vaca.

Desenho 25: líquido obtido dos "corpos glandulares" do outro "testículo" da vaca anterior.

Desenhos 26 a 28: as "bombas animadas", estruturas observadas por Needham no calamar.

Desenhos 29 a 5 1: espermatozóides observados por Leeuwenhoeck; na figura ${ }_{7}$, desenho dos vasos diminutos encontrados entre as partes do sêmen. 
Geração orgâniga, agidente e herança na Carta xiv de Maupertuis

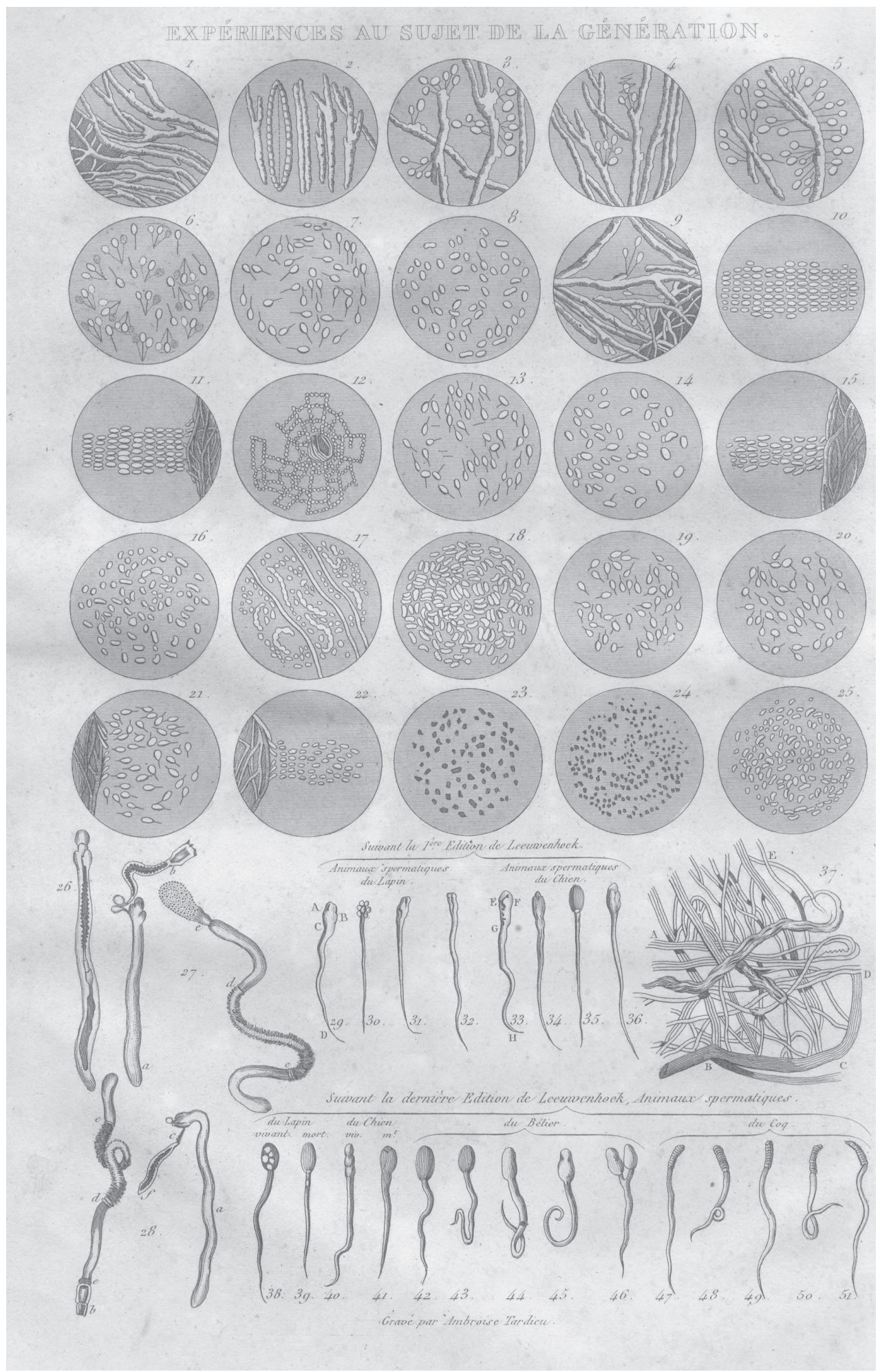


Certifiquei-me pois, pelas experiências que acabo de relatar, que as fêmeas possuem, como os machos, um líquido seminal que contém corpos em movimento; firmei-me cada vez mais na opinião de que esses corpos em movimento não são verdadeiros animais, mas apenas partes orgânicas viventes; convenci-me de que essas partes existem não apenas nos líquidos seminais dos dois sexos, mas na própria carne dos animais e no interior do germe dos vegetais [...] Todos os animais, machos ou fêmeas, todos aqueles que são providos dos dois sexos ou que deles são privados, todos os vegetais, sejam da espécie que forem, todos os corpos, em uma palavra, viventes ou vegetais, são portanto compostos de partes orgânicas viventes que podem ser mostradas aos olhos de todo mundo (Buffon, $185^{3}$, p. $84-5)$.

Em resumo, Maupertuis apresenta na Carta XIV os resultados de Buffon como provas experimentais de sua própria teoria publicada anos atrás na Vênus física. Assim, será importante fazer aqui uma breve comparação das duas teorias.

Os resultados de Buffon a que Maupertuis se refere foram obtidos a partir de estudos realizados em 174,8 no Jardin du Roy com a ajuda de Needham. Tais experiências tinham por objetivo dar uma sustentação empírica a uma teoria geral sobre a reprodução dos organismos que Buffon compôs em 174,6.

A História dos animais, publicada em 1749 no segundo volume da História natural de Buffon, contém duas séries de textos: os primeiros cinco capítulos expõem a teoria geral e os seis seguintes apresentam os resultados experimentais obtidos em 1748 (cf. Roger, 1989, p. 178).

A teoria da reprodução de Buffon fundamenta-se em três noções básicas: as moléculas orgânicas, as forças penetrantes e os moldes interiores. Defendendo a unidade do mundo vivo, Buffon atribui propriedades comuns aos animais e aos vegetais que os separam radicalmente dos seres inanimados. As principais dessas propriedades são o crescimento e a reprodução, ambos bastante relacionados no conjunto da teoria de Buffon. Como Maupertuis, o autor constrói sua teoria tomando de maneira crítica os vários sistemas que trataram da geração e os organiza de uma maneira nova. Segundo Roger,

Para estudar a "reprodução" é preciso começar onde ela é mais simples e Buffon critica aqueles que estudaram apenas a reprodução dos homens e dos mamíferos superiores, a mais complicada. É preciso começar pelos organismos mais simples, aqueles onde uma única parte é capaz de regenerar o organismo inteiro (1989, p. 180). 
É o caso de vários vegetais, alguns vermes e os pólipos. Para Buffon, se um fragmento desses organismos pode reproduzir um organismo completo é porque em cada fragmento há um "germe" do organismo inteiro. Um ormo ou um pólipo é uma reunião de pequenos indivíduos da mesma espécie. Mas esses germes são, por sua vez, também organizados e constituídos por partes orgânicas primitivas que Buffon designará como moléculas orgânicas.

É aqui que podemos perceber como a teoria de Buffon alinha-se claramente à noção geral de uma preformação de partes, tal como discutimos ao expor as teorias dos antigos. É isso também que, essencialmente, permitiu a identificação desta teoria com a de Maupertuis. As moléculas orgânicas, comuns aos animais e vegetais, são indestrutíveis e constituem a matéria primeira da vida; elas retornam ao ambiente após a morte e são novamente incorporadas com o alimento. Deve, portanto, haver um processo interno aos organismos capaz de assimilar as partes orgânicas, separando-as da matéria bruta. Esse processo ocorre graças à existência de "moldes interiores", noção que Buffon toma de Bourguet, mas inclui a ação de uma "força penetrante". Relacionada à atração newtoniana, tal força tem por função integrar as moléculas orgânicas oriundas dos alimentos aos vários órgãos.

Nos organismos simples que se reproduzem a partir de fragmentos corporais, cada germe é um molde interior completo que tem a capacidade de reproduzir um outro organismo adulto. Nos organismos que se reproduzem sexuadamente, cada órgão contém associado seu próprio molde interior e separa as moléculas orgânicas que lhes são próprias ao crescimento; quando o crescimento orgânico estabiliza-se na maturidade sexual, há produção de moléculas orgânicas supérfluas que serão transferidas para os líquidos seminais dos dois sexos. Na cópula, os dois líquidos unem-se e as moléculas orgânicas agregam-se formando um embrião.

A teoria da geração desenvolvida por Maupertuis na Vênus física para dar conta dessas questões é, como já mencionamos, uma versão da antiga teoria hipocrática da dupla semente reinterpretada à luz da química newtoniana da época. Tal como a teoria de Buffon, ela também pode ser designada como uma epigênese dinâmica e, desse modo, poderia ser situada em um dos pólos da controvérsia epigênese-preformação, como usualmente é feito nos estudos históricos sobre a questão. Porém, preferimos não tratar a questão nos termos dessa controvérsia, já que isto exigiria uma discussão mais detida - e fora do escopo desta introdução - sobre a diferença entre preformação e epigênese que comparasse as teorias antigas e modernas sobre a geração.

Segundo Maupertuis, a geração orgânica ocorre a partir da mistura dos líquidos seminais paterno e materno, os quais contêm partes próprias à geração. Tais partes ou partículas gerativas são, então, as verdadeiras unidades reprodutoras, cuja atividade é garantida pela ação de forças especiais de atração, as afinidades químicas. Tais afinidades 
foram postuladas pelo químico francês Geoffroy para explicar a seletividade necessária para a combinação das substâncias nas diversas reações químicas conhecidas. Maupertuis também estabeleceu uma importante analogia entre a produção de certas cristalizações semelhantes a vegetações (fig. 8), como aquela conhecida por Árvore de Diana, e a geração do corpo de uma planta viva. O mesmo aconteceria com os demais corpos organizados: na produção de qualquer organismo, as diferenças de afinidades entre as partes seminais são determinadas por sua origem no corpo dos pais. Partes oriundas de um determinado órgão terão maior afinidade e se atrairão entre si com maior intensidade. Desse modo, pode-se restabelecer no embrião a disposição orgânica semelhante à dos pais.

Podemos ver o quão semelhante são as teorias de Maupertuis e Buffon, que possuem como elementos comuns (1) a teoria hipocrática da dupla semente, (2) a origem pangenética das partes seminais, (3) a natureza corpuscular tanto das moléculas orgânicas quanto das partículas gerativas e (4) a utilização de forças de atração para explicar a agregação das partículas na formação do embrião. Certamente há, junto dessas semelhanças, diferenças importantes como, por exemplo, a noção de molde interior (noção que levou certos autores a interpretar a teoria de Buffon como sendo integral-

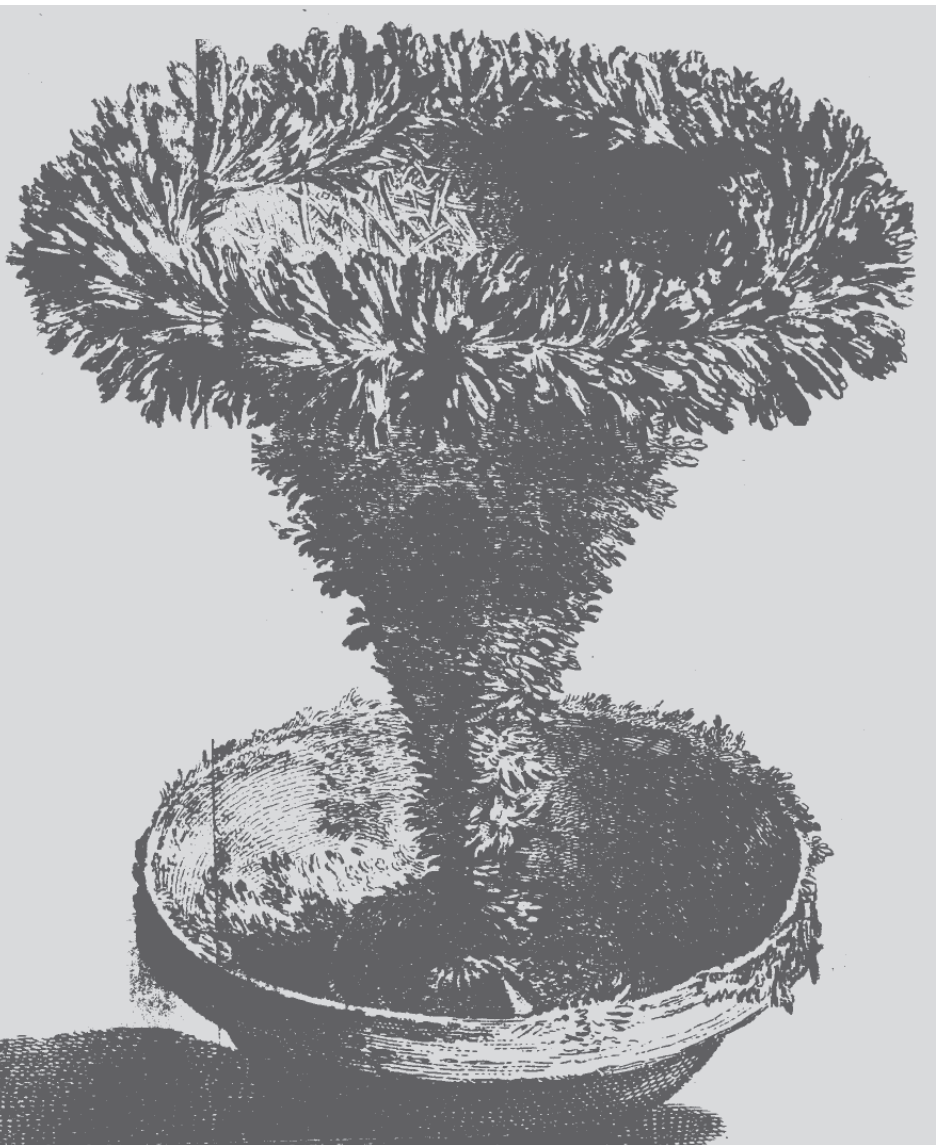

Figura 8. Ilustração de uma árvore química que aparece em um texto citado por Maupertuis na Vênus física, Que as plantas realmente contêm ferro $e$ que este metal entra necessariamente em sua composição natural (1706), de M. Lemery. O processo de produção de uma "árvore de marte" é, resumidamente, o seguinte: "quando vertemos espírito de nitro sobre a limalha de ferro, sabe-se que ocorre uma efervescência violenta acompanhada de forte calor [...] Eu coloquei óleo de tártaro [...] sobre essa dissolução de ferro [...] e pouco tempo depois se formou nas paredes do vaso vários ramos pequenos bem distintos que sempre se elevam do líquido sem fermentação aparente e aumentam continuamente [...] Podemos dar o nome de árvore de ferro ou de marte a essa espécie de vegetação química [...] freqüentemente esses ramos estavam como que guarnecidos de folhas e, no alto, como que portando frutos e flores" (Lemery, 1706 , p. $\left.414^{-} 5\right)$. 
mente preformacionista), mas, na Carta XIV, Maupertuis claramente põe em destaque mais as semelhanças do que as diferenças, já que pretende utilizar os resultados experimentais de Buffon em apoio à sua teoria. Conforme pondera no texto, o sistema que apresentou na Vênus física é "muito semelhante ao do Sr. Buffon e ao qual talvez faltassem apenas suas experiências pra lhe ser ainda mais semelhante" (Maupertuis, 1965, p. 3o4). Maupertuis discute apenas uma pequena diferença, mas muito importante do ponto de vista teórico. Ele considerava os espermatozóides como verdadeiros animais, mas com uma função apenas acessória na geração. Na Vênus física Maupertuis diz que eles servem para agitar os líquidos seminais e, com isso, "aproximar as partes muito distantes e facilitar a união daquelas que se devem juntar fazendo-as apresentarem-se diversamente umas às outras" (Maupertuis, 1965, p. 94). Aceitando agora a teoria de Buffon, Maupertuis deverá aceitar igualmente que os animais do esperma são uma fase da agregação das partículas gerativas no processo de formação do embrião. Isso implicaria em muitas dificuldades e parece que Maupertuis preferiu não entrar em detalhes.

Seja como for, Maupertuis conclui que sua teoria e a de Buffon unem-se para destruir os "sistemas dos ovos e dos animálculos espermáticos" pois "as pretensas observações daqueles que viram ovos nas trompas, fetos inteiramente formados nos ovos e fetos no licor seminal do macho são fabulosas" e o sistema dos antigos, ou seja, a pangênese e a teoria da dupla semente hipocráticas é "o único que se possa racinalmente admitir" (Maupertuis, 1965, p. 305).

\section{Estudos sobre a polidactilia}

Conforme a distinção que estabelecemos no segundo parágrafo deste ensaio, o problema que examinamos no item anterior esteve mais ligado à dimensão ontogenética da geração e que, como vimos ao discutir as teorias antigas, vincula-se à relação entre a constituição e a geração do organismo. Os estudos de Maupertuis sobre a herança da polidactilida que o leitor encontrará na Carta XIV remetem diretamente ao aspecto genético do problema. Sobre ele, em vez de tratar de considerações históricas gerais, como fizemos em relação à ontogênese, discutiremos um aspecto mais conceitual particular. Trata-se da interpretação dos estudos genéticos de Maupertuis como "precursores" da genética mendeliana. Pensamos que esta pode ser uma das primeiras coisas a chamar a atenção do leitor e, sem entrar em todos os detalhes que a questão sucita, apresentaremos alguns de seus elementos, especialmente sobre o significado dos cálculos probabilísticos apresentados por Maupertuis.

Bentley Glass foi um dos autores que afirmou que Maupertuis poderia ser considerado como precursor de Mendel. Nas conclusões de um de seus artigos escreve: 
Poderíamos deixar de concluir que este homem foi quem [...] investigou, duas centenas de anos atrás, a hereditariedade humana de modo a, por assim dizer, ganhar a admiração de qualquer geneticista atual e quem aplicou a teoria matemática da probabilidade à genética mais de um século antes de Mendel? (Glass, 1947, p. 209).

Em um artigo posterior, afirma cabalmente que "Maupertuis antecipou virtualmente cada idéia do mecanismo mendeliano de hereditariedade" (Glass, 1955, p. 107).

Iris Sandler examinou posteriormente essa tese em um estudo bem mais detalhado da questão e concluiu precisamente o contrário. Com relação aos referidos cálculos de probabilidade, afirma que:

Maupertuis lidou com probabilidade subjetiva ou epistemológica, enquanto Mendel explorou o domínio da probabilidade aleatória. Mais uma vez, Maupertuis e Mendel dedicaram-se eles próprios a diferentes objetivos e a questão do precursor é inaplicável (Sandler, 1983, p. 134).

É sobre essa diferença de aplicação da probabilidade que propomos fazer algumas breves considerações.

O objetivo imediato visado por Maupertuis para seus estudos sobre a polidactilia é fornecer uma evidência empírica adicional a favor da herança biparental e, com isso, reforçar a refutação da preexistência. Podemos dizer que esses resultados são a contri-

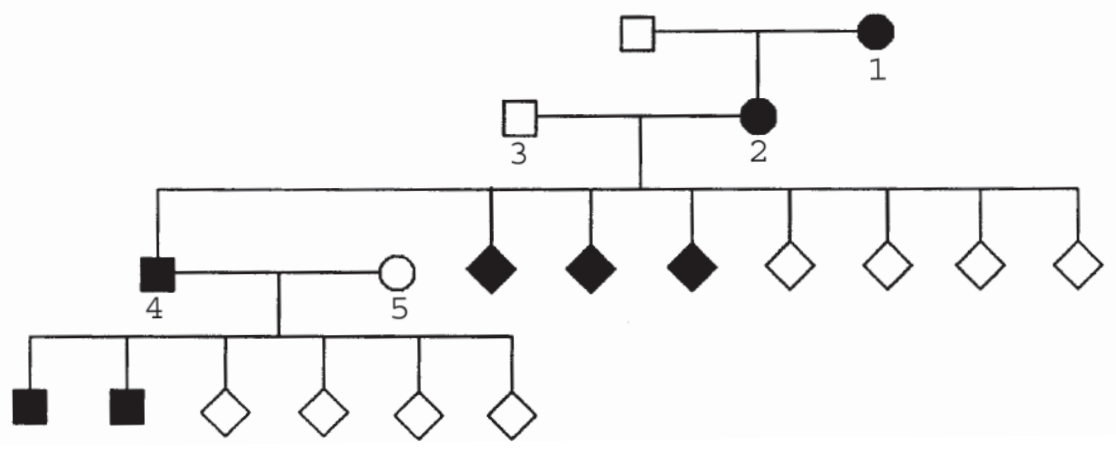

Figura 9. Heredograma da família Ruhe levantada por Maupertuis em seu estudo da hexadactilia; 1 Elizabeth Horstmann; 2 - Jean Ruhe; 3 - Elisabeth Ruhe; 4 - Jacob Ruhe; 5 -S. L. de Thüngen. As figuras cheias representam os indivíduos hexadáctilos; os quadrados, homens; os círculos, mulheres; os quadrados inclinados, sexo desconhecido. 
buição empírica que Maupertuis reconheceu carecer na Vênus fisica. O problema da polidactilia é introduzido com uma referência à obra de Réaumur, $A$ arte de fazer eclodir aves domésticas. Maupertuis lamenta que os resultados das experiências ali propostas sobre a herança dos dedos e do uropígio em galinhas não tenham sido apresentadas, já que eles poderiam "decidir se o feto é o produto apenas do pai, apenas da mãe ou de ambos conjuntamente" (Maupertuis, 1965, p. 3०6). Mas, logo em seguida, o autor diz que existe uma experiência melhor já realizada: trata-se da transmissão da hexadactilia (a presença de um sexto dedo nas mãos e nos pés) na família de Jacob Ruhe, cirurgião de Berlim, cuja genealogia Maupertuis reconstruiu procurando traçar o caminho hereditário desse caráter mutante. O heredograma que apresentamos na figura 9 ilustra e sintetiza a descrição apresentada no texto. Um rápido exame da figura mostra com clareza que o caráter pode ser transmitido tanto pelo pai quanto pela mãe e, assim, aparece como uma forte evidência empírica contra a herança monoparental das duas versões da preexistência.

Apesar desses resultados atingirem plenamente o objetivo do autor, ele não deixou de examinar uma hipótese que poderia ser levantada contra sua conclusão: todos esses nascimentos de indivíduos com dedos supranumerários poderiam ter sido obras do acaso e, portanto, não sendo hereditários, nada provariam contra a preexistência. Para testar tal hipótese, Maupertuis realiza o estudo em que aplica o cálculo de probabilidade a que estamos nos referindo. Acompanhando tais cálculos no texto, vemos que o resultado final obtido é que a probabilidade de que nasçam por acaso três indivíduos hexadáctilos na mesma família (a do cirurgião Jacob Ruhe) é de 1:8x10 ${ }^{12}$. Na verdade, Maupertuis apresenta no texto esse resultado de forma invertida, ou seja, que "a probabilidade de que essa singularidade não continuaria por três gerações sucessivas seria de 8.000.000.000.000 para 1" e, logo após concluir seus cálculos, afirma que tais números são "tão grandes que a certeza das coisas melhor demonstradas em física não se aproxima dessas probabilidades" (Maupertuis, 1965, p. 3०9-10). É a partir dessa última conclusão que aparece o problema da relação entre a genética de Maupertuis e a de Mendel no que diz respeito à aplicação do cálculo de probabilidades.

Sandler apóia seu argumento na distinção entre duas formas de aplicação da probabilidade, a saber, a probabilidade epistemológica, utilizada quando se deseja sustentar o grau de credibilidade de uma afirmação, e a probabilidade estatística ou aleatória, usada para identificar a tendência de certos fenômenos dependentes do acaso, após um grande número de repetições, exibirem alguma regularidade (Sandler, 1983, p. 124). Assim, esta última afirmação citada de Maupertuis mostra que o autor está apresentando fortes evidências empíricas para sustentar a crença de que a hexadactilia não é fruto do acaso, mas um fenômeno hereditário. Conforme esclarece Beeson, o autor estaria testando o que atualmente designaríamos como uma hipótese nula: 
Se a hipótese nula fosse verdadeira [isto é, que a hexadactilia não é hereditária], a probabilidade contra o aparecimento tão freqüente do traço na família Ruhe seria maciça. Ele concluiu, então, que poderia, com o que chamaríamos atualmente um alto grau de confiança, rejeitar a hipótese nula como falsa (Beeson, 1992, p. 235$)$.

Assim, Maupertuis claramente valeu-se de uma aplicação epistemológica da probabilidade. Mendel, ao contrário, segundo a interpretação de Sandler, utilizou a probabilidade para "tratar estatisticamente uma população de gametas cuja união era uma função do acaso" (Sandler, 1983, p. 128), ou seja, a probabilidade é utilizada no estudo de regularidades naturais - o encontro fortuito de gametas - e nada tem a ver com a medida de nosso grau de conhecimento ou de ignorância. Segundo a autora, tal diferença de aplicação é suficiente, no que depende disso, para negar a tese de que Maupertuis é precursor de Mendel.

\section{NOVAMENTE OS ANIMÁLCULOS: DÚVIDAS E QUESTÕES}

Na parte final da Carta XIV, Maupertuis volta ao tema da diversidade de estruturas microscópicas observadas por Buffon e Needham. O problema que tais observações colocam é, novamente, a natureza das unidades gerativas: dentre tantas estruturas observadas, com as mais diferentes formas e comportamentos, quais delas considerar como verdadeiros "animais"? Em que medida a divisibilidade da vida acompanha a divisibilidade da matéria? Para que o leitor possa avaliar a importância e o efeito que essas observações tiveram sobre Maupertuis, reproduzimos abaixo o trecho principal de uma carta que escreveu a La Condamine em 1750, período em que, como mencionamos, já trabalhava na composição das Cartas:

Lestes o livro de Needham? Onde estamos? Que novo universo! Que lamentável que um homem que observa tão bem raciocine tão mal! Aconteceu-me após a leitura de seu livro ficar com o espírito tão aturdido com todas as idéias que ele me apresentou que precisei me deitar como se estivesse doente; e ainda não estou muito bem refeito da perturbação em que essa leitura me colocou. Espero, quando este tumulto estiver um pouco mitigado, retomar o fio de algumas meditações que comecei há algum tempo sobre esse assunto e ver se é possível sobre ele oferecer alguma coisa de razoável.

É possível que, em vossa Academia, Réaumur, que verdadeiramente possui tantos talentos para a história natural, considere essas experiências e as de Buffon 
como indiferentes e se divirta fazendo chocar ovos enquanto se descobre um novo mundo? Se eu estivesse no lugar do Sr. D'Argenson, proibiria todos os físicos da Academia de se ocupar com outra coisa [...]. É aqui que se pode dizer que a estrutura do menor inseto é mais maravilhosa do que a de todo sistema planetário. Eu não sei de onde Needham pode retirar todas as bizarrias que propõe; ele deveria deixar Buffon raciocinar e Buffon também deixa nesta matéria uma terrível desordem, mas da qual talvez não será possível sair (Maupertuis, [s.d.]).

O livro a que Maupertuis se refere aqui, também citado no documento, é o Novas descobertas microscópicas que, segundo Beeson (1991, p. 207), o autor possivelmente lera na edição parisiense de $175^{\circ}$. As estruturas que chamaram a atenção de Maupertuis são as "bombas animadas" presentes no líquido seminal do calamar e que "não se assemelham nem às moléculas do Sr. de Buffon nem ao animal no qual se encontram" (Maupertuis, 1965, p. 313). Needham mostrou tais estruturas a Buffon durante as experiências que realizaram juntos e, no final do capítulo seis da História dos animais, após tecer um longo comentário sobre elas, Buffon conclui:

Eu vi em seu microscópio e com ele [Needham] essas mesmas máquinas do esperma do calamar e pudemos assegurar-nos que a descrição que ele oferece é muito fiel e exata. Essas observações fazem-nos ver, portanto, que a semente é composta de partes que procuram se organizar, que ela produz, com efeito, dentro de si mesma um corpo organizado, mas que esses corpos organizados não são ainda animais semelhantes ao indivíduo que os produz (Buffon, $185^{3}$, p. $7^{6}$ ).

Em princípio, essas estruturas, como outras quaisquer dotadas de movimento e de vida encontradas nos líquidos seminais, serão interpretadas como reuniões iniciais de moléculas orgânicas que ainda não são semelhantes ao indivíduo parental, mas que virão a sê-lo. Mas logo em seguida, Buffon atribui uma outra função para as "bombas" do esperma do calamar: "Poderíamos ainda acreditar que esses corpos organizados são apenas espécies de instrumentos que servem para aperfeiçoar o líquido seminal e para impeli-lo com força e que é por essa ação viva e interior que ele penetra mais intimamente no líquido da fêmea" (Buffon, $185^{3}$, p. $7^{6}$ ), explicação bem semelhante àquela de Maupertuis a que nos referimos anteriormente.

A Carta XIV também faz referência às "enguias da farinha dissolvida" e aos "filetes animados" dos grãos de trigo com ferrugem, que também seriam, pela teoria de Buffon, tantas outras reuniões de moléculas orgânicas, tal como os próprios espermatozóides. Mas esses fenômenos são, declara Maupertuis "uma maravilha ainda maior": as enguias da farinha podem surgir tanto espontaneamente quanto se reproduzir como 
os animais vivíparos e os filetes do trigo, uma vez umedecidos, ressuscitam após permanecerem inertes e sem vida por anos inteiros.

Podemos aqui entender o espanto de Maupertuis que lemos em sua carta a La Condamine e que é igualmente expresso na Carta XIV. Um "novo universo" é revelado pelo microscópio de Needham e, entre as teóricas partículas gerativas dos líquidos seminais e os animais que vemos habitualmente, há um mundo intermediário de seres, em vários estágios de organização e com os mais variados comportamentos. Em princípio, as forças atrativas de Buffon e as afinidades químicas de Maupertuis talvez pudessem dar conta de toda essa nova diversidade, mas a questão que Maupertuis formula nas linhas finais da Carta XIV revelam sua intenção de dar um novo rumo para sua teoria: seriam as forças de atração suficientes para explicar universalmente todos esses fenômenos ou "seria preciso ainda alguma coisa a mais"? A resposta a essa pergunta será dada em sua obra definitiva sobre o assunto, o Sistema da natureza:

Uma atração uniforme e cega espalhada em todas as partes da matéria não poderia servir para explicar como essas partes se arranjam para formar os corpos cuja organização é a mais simples. Se todas têm a mesma tendência, a mesma força para unirem-se umas com as outras, por que estas vão formar o olho e aquelas a orelha? Por que esse arranjo maravilhoso? E por que todas elas não se unem confusamente? (Maupertuis, 1965, p. 146).

As afinidades químicas, ou mesmo as forças penetrantes de Buffon, seriam formas variadas de atração, cuja diversidade poderia dar conta da diversidade de elementos orgânicos a serem gerados. Porém, para que a geração dos habitantes desse "novo universo" revelado pelo microscópio de Needham pudesse ser explicada, seria necessário postular tantos tipos diferentes de afinidades ou forças semelhantes que a busca de um princípio gerativo universal perderia todo o sentido; no limite, seria necessário supor que existem "tantas [atrações] quantas partes diferentes no interior da matéria" (Maupertuis, 1965, p. 1411). Por tais razões, Maupertuis substitui as forças de atração pelas propriedades psíquicas desejo, aversão e memória. Quando um embrião está se formando, a atração espalhada por todas as partes da matéria não será mais uniforme e cega, pois sua intensidade poderá variar segundo a aversão ou o desejo dos elementos materiais por estabelecer certas interações e a direção da ação dessa força será orientada por uma memória capaz de indicar a localização espacial adequada à organização do corpo em formação. Essa teoria constitui o estágio final das pesquisas de Maupertuis sobre a geração orgânica e, como dissemos anteriormente, ele pretendeu ter com ela explicado todos os fenômenos gerativos da época, inclusive aqueles que, na Carta XIV, apareciam como surpreendentes e que motivaram as várias questões ali formuladas. 
Essa opção por um psiquismo associado à matéria como princípio explicativo mais fundamental do que a química das atrações constitui um caso exemplar das transformações sofridas pelas ciências da vida no século xvııI e, nesse sentido, a Carta XIV aparece como um importante documento revelador de um momento crucial de escolha teórica diante dos novos dados empíricos revelados pelas observações microscópicas.

\author{
Maurício de Garvalho Ramos \\ Pesquisador do Projeto Temático \\ "Estudos de filosofia e história da ciência" da Fapesp, \\ pós-doutorando do Departamento de Filosofia \\ da Universidade de São Paulo. \\ maucramos@aol.com
}

\title{
REFERÊNGIAS BIBLIOGRÁFIGAS
}

Aristóteles. In: Souza, J. G. de (Org.). Os pré-socráticos. Trad. de P. F. Flor. São Paulo, Abril Cultural, 1973. (Os Pensadores, 1 ).

Beeson, D. Maupertuis: an intellectual biography. Oxford, The Voltaire Foundation/The Alden Press, 1992. Buffon, G.-L. de. Oeuvres, avec des extraits de Daubenton et la classification de Cuvier. Paris, Furnet, $185^{3}$. v. 3.

CAstañeda, L. A. As idéias pré-mendelianas de herança e sua influência na teoria de evolução de Darwin. Campinas, 1992. Tese (Doutorado em Ciências). Instituto de Biologia, Universidade Estadual de Campinas.

Fischer, J.-L. La naissance de la vie. Paris, Pocket, 1991.

Gasking, E. B. Investigations into generation 1651-1828. London, Hutchinson, 1967.

GLAss, B. Maupertuis and the beginnings of genetics. The Quarterly Review of Biology, 22, p. 197-210, 1947 . Maupertuis, a forgotten genius. Scientific American, 193, p. 104,-7, 1955.

Graff, R. de. De mulierum organis. In: Fischer, J.-L. La naissance de la vie. Paris, Pocket, 1991. p. 25-44.

Hipócrates. On the sacred disease. In: Hutchins, R. M. (Ed.). Great books of the western world: Hippocrates, Galen. Chicago, Encycloppaedia Britannica, 1952. p. 154-60.

HoffheImer, M. H. Maupertuis and the 18th-century critique of pre-existence. Journal of the History of Biology, 15 , p. 119-44, 1982.

Hutchins, R. M. (Ed.). Great books of the western world: Hippocrates, Galen. Chicago, Encycloppaedia Britannica, 1952 .

Iвraнiм, A. Matière inerte et matière vivante: la théorie de la perception chez Maupertuis. Dix-Huitième Siècle, 24, p. 95-103, 1992.

Joyau, E. \& Ribbeex, G. (Org.). Epicuro, Lucrécio, Cícero, Sêneca, Marco Aurélio. Trad. e notas de A. da Silva. São Paulo, Abril Cultural, 1973. (Os Pensadores, 5 ).

Kirk, G. S.; Raven, J. E. \& Schofield, M. Os filósofos pré-socráticos. Lisboa, G. Gulbenkian, 1994. 
Lemery, M. Que les plantes contiennent réelement du fer, \& que ce métal entre necessairement dans leur composition naturelle. Mémoires de l'Academie Royale des Sciences, 1706. p. 411-8.

Lucrécio. Da natureza. In: Joyau, E. \& Ribbeex, G. (Org.). Epicuro, Lucrécio, Cícero, Sêneca, Marco Aurélio. Trad. e notas de A. da Silva. São Paulo, Abril Cultural, 1973. p. 31-14.0. (Os Pensadores, 5).

Maupertuis, P-L. M. de. Lettre a La Condamine du 24, août 1750. Archives d'llle-et-Vilaine. St-Malo, II 24, [s. d.]. Cópia de manuscrito inédito.

. Observation et expériences sur une des espèces de salamandres. Mémoires del'Académie de Sciences de Paris, 1727 , p. 27-32.

Expériences sur les scorpions. Mémoires de l’Académie des Sciences de Paris, 1731. p. 223-9.

. Oeuvres. Hildesheim, Georg Olms, 1965. v. 2. Fac-símile da edição de 1768, Lyon.

Papavero, N. \& Balsa, J. Introdução histórica à biologia comparada, com especial referência à biogeografia. Belo Horizonte, Biótica/Sociedade Brasileira de Zoologia, 1986. v.1: Do gênesis à queda do império romano do ocidente.

Ріснот, A. Histoire de la notion de vie. Paris, Gallimar, 1993.

Platão. In: Souza, J. C. de (Org.). Os pré-socráticos. Trad. de P. F. Flor. São Paulo, Abril Cultural, 1973. (Os Pensadores, 1).

Ramos, M. de C. Origem da vida e origem das espécies no século xviII: as concepções de Maupertuis. Scientiae Studia, 1, 1, p. 4,3-62, 2003.

Roger, J. Buffon. Paris, Fayard, 1989.

. Les sciences de la vie dans la pensée française au xvııı siècle. Paris, Albin Michel, 1993.

SANDLER, I. Pierre Louis Moreau de Maupertuis: a precursor of Mendel? Journal of the History of Biology, 16, 1, p. 101-36, 1983.

Simplício. In: Souza, J. G. de (Org.). Os pré-socráticos. Trad. de P. F. Flor. São Paulo, Abril Cultural, 1973. (Os Pensadores, 1 ).

Souza, J. C. de (Org.). Os pré-socráticos. Trad. de P. F. Flor. São Paulo, Abril Cultural, 1973. (Os Pensadores, 1 ). 